\title{
気泡微細化を伴うサブクール流動沸騰 (円管流路の長さと除熱限界)
}

\section{Subcooled Flow Boiling with Microbubble Emission \\ (Effect of length of circular tube on cooling limit)}

\author{
○学 佐藤 真也（東理大院） \\ 正 鈴木 康一（東理大） \\ Masaya Sato and Koichi Suzuki, Tokyo University of science, 2641 Yamasaki, Noda, Chiba
}

\begin{abstract}
Highly subcooled flow boiling of water was performed for a horizontal circular channel with $5 \mathrm{~mm}$ in diameter and $50 \mathrm{~mm}$ in length of heating section. Microbubble emission boiling (MEB) occurred in the upstream section of heating surface and the heat flux increased at higher liquid velocity than $0.25 \mathrm{~m} / \mathrm{s}$. The maximum heat flux was $4.5 \sim 5 \mathrm{MW} / \mathrm{m}^{2}$ in the upstream section of $5 \sim 15 \mathrm{~mm}$ apart from the edge of the heating surface at $40 \mathrm{~K}$ of liquid subcooling and $1.0 \mathrm{~m} / \mathrm{s}$ of liquid velocity. However, the local heat flux decreased gradually in the down stream section and the liquid is almost evaporated at the exit of heating section. The experimental results show that MEB is difficult to occur for longer sized heating surface than $15 \mathrm{~mm}$.
\end{abstract}

Key Words: Subcooled flow boiling, Transition boiling, Circular channel, MEB, Long heating surface, High heat flux

1.ま宇がき

近年, コンピュータのCPUを始めとする電子素子の性能 向上と共に, 発熱密度も増加している. 将来ハイブリッド カーや電気自動車に用いられる電力変換用電子機器の発熱 密度は $200 \mathrm{~W} / \mathrm{cm}^{2}$ とも $300 \mathrm{Wc} / \mathrm{m}^{2}$ とも予測されている。こ のような高熱流束の除熱には，沸騰冷却が有効と考えられ るが，除熱限界である限界熱流束(CHF: Critical Heat Flux) を超えると制御不能な遷移沸騰を経て高温の膜沸騰に移行 し，バーンアウト（焼切れ）を起こす危険があるため, 電 子機器の冷却には困難とされてきた。

最近，高サブクール流動沸騰において，遷移沸騰領域で 通常の限界熱流束よりも熱流束が高い気泡微細化沸騰 (MEB)の発生が報告されている(1) (3)。 その熱流束は $10 \mathrm{MW} / \mathrm{m}^{2}$ 以上にも及ぶ(4). MEB は上述の高熱流束除熱に 期待できるが，現在 $40 \mathrm{mmL} \times 10 \mathrm{mmW}$ までの平板伝熱面 ${ }^{(5)}$ および長さ $10 \mathrm{~mm}$ の円管伝熱面 ${ }^{(6)}$ の小さ伝熱面について 得られたものである。

本研究は内径 $5 \mathrm{~mm}$, 長さ $50 \mathrm{~mm}$ の伝熱面を有する円管流 路にサブクール流動沸腾を行わせ, MEB を含む除熱特性に ついて調べたものである.

\section{2. 実験}

テストセクションは図 1 に示すように銅ブロックと円管 で構成され, 円管の直径 $5 \mathrm{~mm}$, 伝熱面長さ $50 \mathrm{~mm}$ である. 加 熱は円周上に 35 本のカートリッジヒーターを挿入して行 った. 伝熱面の端から $5 \mathrm{~mm}, 15 \mathrm{~mm}, 25 \mathrm{~mm}, 35 \mathrm{~mm}, 45 \mathrm{~mm}$ の位置 に, 伝熱面から $3 \mathrm{~mm}, 7 \mathrm{~mm}, 11 \mathrm{~mm}$ の距離で直径 $0.5 \mathrm{~mm}$ のシ ース $\mathrm{K}$ 型熱電対を挿入し温度を測定した (図 2). 局所伝熱 面過熱度および局所熱流束は測定した温度分布から求めた。

実験装置の概略を図 3 に示す。液体には蒸留水を用い高 温槽とテストセクションの間をフローメーター，フィルタ 一，マントルヒーターを通して循環させた．液体のサブク ール度はテストセクション入り口で設定温度から $3 \mathrm{~K}$ 以内 に維持し，管内流速は流量と円管の断面積から計算した。 流路出口のバルブを調整し、テストセクションの流路内を 大気圧に保持した。

3. 結果および考察

3.1 短い $(10 \mathrm{~mm})$ 長さの伝熱面のサブクール流動沸騰 テストセクション入口のサブクール度が $30 \mathrm{~K}$ 以上におい
て管径 $5 \mathrm{~mm}, 10 \mathrm{~mm}$ 共に安定した MEB が発生した。実験 結果の例として, サブクール度 $40 \mathrm{~K}$, 流路内平均流速 $0.25 \mathrm{~m} / \mathrm{s}$ および $1 \mathrm{~m} / \mathrm{s}$ の沸騰曲線を図 4 および 5 に示す。図 4 および図 5 において, 流速が $0.25 \mathrm{~m} / \mathrm{s}$ の遅い場合, 図 4

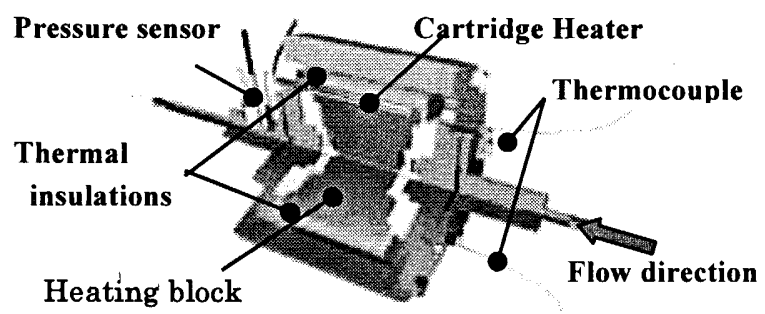

Fig.1 Test section

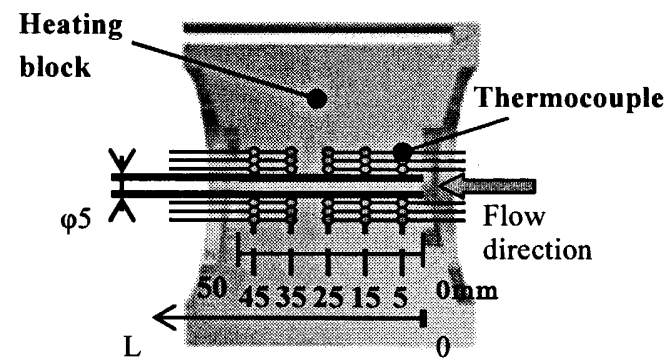

Fig. 2 Measuring points in heating block Heating surface; $\varphi 5 \mathrm{~mm} \times 50 \mathrm{~mm}$ in length

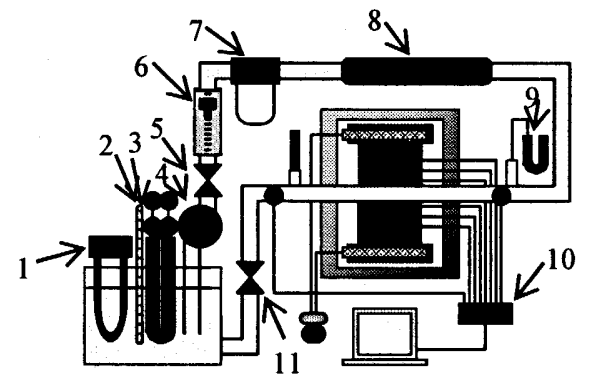

1.Cooler 2.Thermometer 3.Heater 4.Water pump 5.Regulating valve 6.Flow meter 7.Filter 8.Mantle heater 9.Manometer 10.A/D converter 11. Regulating valve

Fig.3 Experiment arrangement 
に示すように管径 $10 \mathrm{~mm}$ の熱流束は $5 \mathrm{~mm}$ の熱流束よりも 高いが，流速が増加するにつれてその差は小さくなり，図 5 に示すように, 流速 $1 \mathrm{~m} / \mathrm{s}$ においては管径の違いによる熱 流束の差はほとんど見られなくなる．流速が遅い場合は, 質量流量による凝縮効果が支配的になり，流速が早くなる につれて伝熱面上の気泡の除去効果が大きくなってくるも のと考えている.

3.2 長い $(50 \mathrm{~mm})$ 長さの伝熱面のサブクール流動沸騰

直径 $5 \mathrm{~mm}$, 長さ $50 \mathrm{~mm}$ の伝熱面では, 上流端から $5 \mathrm{~mm}, 15 \mathrm{~mm}, 25 \mathrm{~mm}, 35 \mathrm{~mm}$ および $45 \mathrm{~mm}$ における局所伝熱面 過熱度および熱流束を測定した. サブクール度 $30 \mathrm{~K}$, 流速 $0.25 \mathrm{~m} / \mathrm{s}$ および $1.0 \mathrm{~m} / \mathrm{s}$ の結果を図 6 および図 7 に示す.

$0.25 \mathrm{~m} / \mathrm{s}$ の低流速では, 図 6 に示すように, サブクール度 が 20-40Kにおいて MEB の明確な発生は確認できなかった. さらに加熱を続けると, 伝熱面温度が急上昇し膜沸騰に移 行する傾向がみられた.

流速 $1 \mathrm{~m} / \mathrm{s}$ の高流速では, 図 7 に示すように, 伝熱面上流 部 $(5 \mathrm{~mm}, 15 \mathrm{~mm})$ において MEB が発生し, CHF 後に熱流束が 增加している。 しかし, 伝熱面下流側では伝熱面の温度上 昇に伴い熱流束が減少している.

円管流路で $10 \mathrm{~mm}$ より長い伝熱面の場合，伝熱面下流の サブクール度が減少し，下流部では MEB が発生しなくな る.また，流速が遅くなるとさらにその傾向は強くなる， 管直径が $5 \mathrm{~mm}$ の場合, 流速 $1 \mathrm{~m} / \mathrm{s}$ では伝熱面長さは $15-20 \mathrm{~mm}$ 程度が MEB 発生の限界と考える。

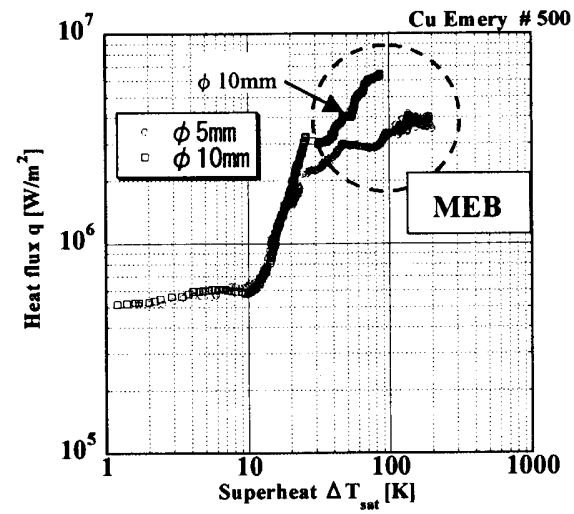

Fig.4 Boiling curves for different channels with $5 \mathrm{~mm}$ and $10 \mathrm{~mm}$ diameter at $40 \mathrm{~K}$ of liquid subcooling and $0.25 \mathrm{~m} / \mathrm{s}$ of liquid velocity

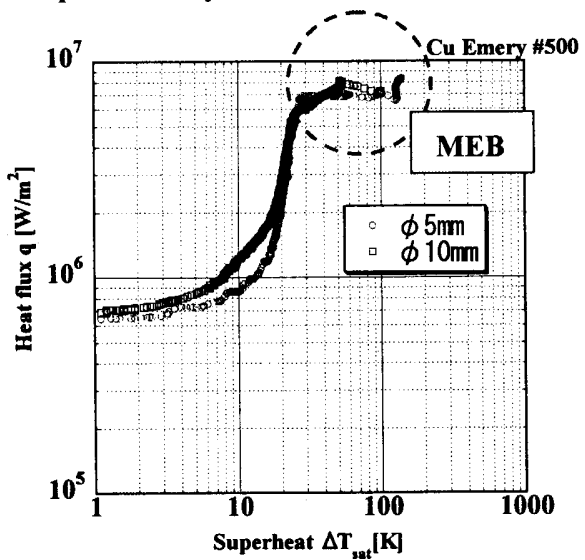

Fig.5 Boiling curves for different channels with $5 \mathrm{~mm}$ and $10 \mathrm{~mm}$ diameter at $40 \mathrm{~K}$ of liquid subcooling and $1 \mathrm{~m} / \mathrm{s}$ of liquid velocity
4. まとめ

短い伝熱面では気泡微細化沸騰は発生し易いが，長い伝 熱面ではサブクール度 $30 \mathrm{~K}$, 管内平均流速 $1.0 \mathrm{~m} / \mathrm{s}$ で発生す るが，短い伝熱面の場合に比べて気泡微細化沸騰は発生し にくい. また, 気泡微細化沸騰が発生して高熱流束が期待 できるのは，伝熱面の上流側で，上流端から $15 \mathrm{~mm}$ を過ぎ たあたりから, 熱流束は減少し, 膜沸騰に移行しやすい.

円管流路にサブクール水を通して気泡微細化沸騰を発生 させ, 高熱流束を期待する場合, 伝熱面（冷却部）の長さ は，15mm 20mm 以下でないと難しい，

本研究は, 日本学術振興会の平成 14 年度 16 年度科学 研究費補助金によって行われたものである.

文 献

(1) Fujibayashi,et al., Trans. JSME, Vol.51, No.463, pp.919-926 (1985).

(2) Kubo,R.,et al.,Trans. JSME, Vol.58, No.546,pp.497-502, (1992).

（3）鈴木他 4 名, 機論 BVol.65, No.637, pp.3097-3104 (1999).

(4) Kumagai S, et al., Proc. 6 th ASME-JSME Thermal Engineering Conf. CD-ROM, TED-AJ 03-219 (2001).

(5) Suzuki,K., et al., Annuals of New York Academy of Sciences, 974. pp.364-377 ( 2003).

(6) Suzuki K., et al., Proc. 1st Intl. Symp. Micro-Nano Tech.,CD-ROM V1-01.(2004).

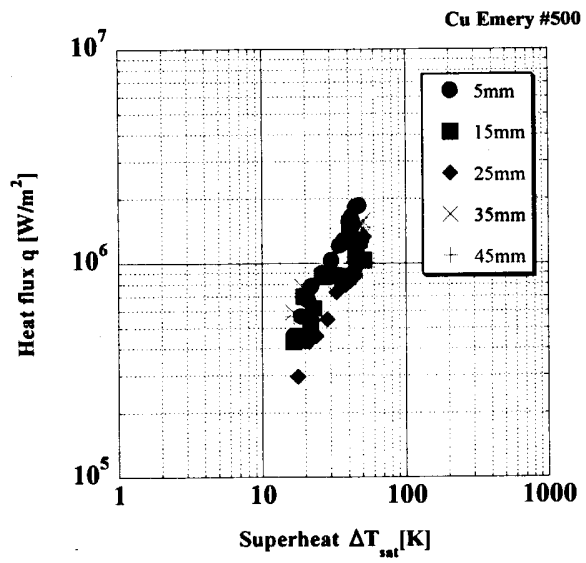

Fig. 6 Local boiling curves for long heating surface at $30 \mathrm{~K}$ of liquid subcooling and $0.25 \mathrm{~m} / \mathrm{s}$ of liquid velocity

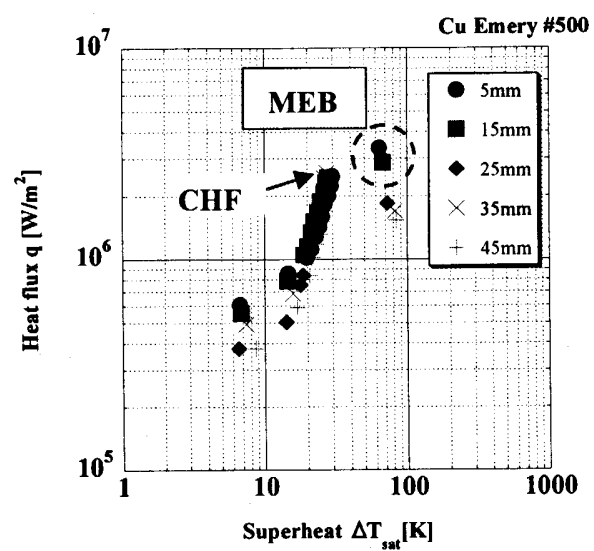

Fig.7 Local boiling curves for long heating surface at $30 \mathrm{~K}$ of liquid subcooling and $1.0 \mathrm{~m} / \mathrm{s}$ of liquid velocity 